\title{
Pap Smear Abnormalities in Adolescents and Young Women
}

Gianna Roselli Venâncio', Márcia Fuzaro Terra Cardial' Salomon Katz ${ }^{2}$, Rodolfo Strufaldi', Luciano Melo Pompei ${ }^{1}$

\section{Abstract}

Introduction: Adolescence is a period in the life of a woman characterized by significant physical and psychological changes. In various places in the world it is also the period in which sexual activity usually begins. Sexual activity has been occurring increasingly earlier in adolescents.

Objective: To evaluate the prevalence of Pap smear abnormalities in adolescents and young women (MJA) compared to adult women (MA).

Methods: Cross-sectional study of cervical uterine cytology obtained from women in Santo André (SP, Brazil) between January 2009 and December 2011, comparing the cytological results between MJA (age: 14-24 years) and MA (age: 25 years or over).

Results: 92,118 exams evaluated; 76,752 in the MA group and 15,366 in the MJA group. Of the total, 89,723 were normal and 2,395 abnormal $(1,278$ [53.4\%] corresponded to atypical squamous cells of undetermined significance [ASCUS], 900 [37.6\%] to low-grade squamous intraepithelial lesion [LSIL] and 217 [9.1\%] to high-grade squamous intraepithelial lesion [HSIL]). There were 510 (3.3\%) abnormal tests in the MJA group and 1,885 (2.5\%) in the MA group, of which 217 (42.5\%) and 1061 (56.3\%), respectively, were classified as ASCUS, 280 (54.9\%) and 620 (32.9\%), respectively, as LSIL, and 13 (2.5\%) and 204 (10.8\%), respectively, as HSIL. Conclusion: The most frequent abnormality in the MJA group was LSIL and in the MA group was ASCUS. HSIL was 4 times more frequent in adult women in comparison to young women and adolescents.

\footnotetext{
Keywords

Adolescent; Uterine Cervical Neoplasms; Cervical Intraepithelial Neoplasia;

Cervical Cancer Prevention.
}

1 Departamento de Ginecologia e Obstetricia da Faculdade de Medicina do ABC, Santo Andre, SP, Brazil.

2 Laboratório de Análises Clínicas Salomon Katz.

Contact information:

Luciano de Melo Pompei.

Address: Av. Príncipe de Gales, 821 -

Príncipe de Gales - Santo André -

SP - CEP: 09060-650.

Tel: (11) 4993-7227.

झ luciano.pompei@fmabc.br 


\section{Introduction}

Adolescence is a period in the life of a woman characterized by significant physical and psychological changes. In various places in the world it is also the period in which sexual activity usually begins. Sexual activity has been occurring increasingly earlier in adolescents.

A survey carried out in 2006 by the Centro Brasileiro de Análise e Planejamento do Ministério da Saúde found that the average age for initiating sexual activity in adolescents was 15.2 years (32.6\%), although adolescents with a higher level of education (9-11 years of education) started sexual activity at a later age (on average 18.2 years old) [1].

Data from the Pesquisa Nacional de Saúde do Escolar (PeNSE), 2009, covering the main cities in Brazil, have shown that approximately $30.5 \%$ of ninth-grade students have already initiated sexual activity, a larger proportion being boys (43.7\%) in comparison to girls (18.7\%). In 2012, the percentages were $40.1 \%$ for boys and $18.3 \%$ for girls [2].

Young girls who start sexual activity early, if not adequately guided, may be more vulnerable to unplanned pregnancies and have an increased risk of sexually transmitted diseases (STDs). In the case of human papilloma virus (HPV), which is currently the most comum of the STDs, it is estimated that between $25 \%$ and $50 \%$ of women and $50 \%$ of men in the world are infected by one or more of the 120 types of human papilloma virus [3].

During adolescence, cervical biological activity is at its highest, with cell replication and substances in the cervical region that facilitate HPV infection [4]. After adolescence, the frequency of infection by HPV tends to decrease in women as they get older [5].

Epidemiological studies have shown that the risk of cervical cancer is highly influenced by early sexual activity, where the number of partners has an influence on the association between the first sexual encounter and HPV infection. Other factors are also involved, such as the use of alcohol, drugs, smoking, hormonal contraception and a previous history of STDs [6].

In Brazil in 2012, there was an incidence of 15,590 new cases of cervical cancer, with an estimated risk of 15.33 cases for every 100,000 women [7].

The prevalence of intraepithelial lesions induced by HPV has increased over the last decades, and the average age at the time of diagnosis has decreased, with an increase in the frequency thereof among adolescents and women under 30 years of age [8].

Due to a higher rate of HPV infection in youngsters and an increase in the prevalence of intraepithelial lesions in this population, it is feared that there will be a consequent increase in the incidence of cervical cancer over the next years. This would be a huge challenge for the health services worldwide, and, although the risk of cervical cancer is low in this group, it is not zero, and the national guidelines on screening for cervical cancer do not recommend including women under 25 years of age $[9,10]$.

Due to concerns of a possible increase in lesions that can lead to cervical cancer in younger women, the aim of this study is evaluate the prevalence of Pap smear abnormalities in adolescents and young women (MJA) compared to adult women (MA).

\section{Methods}

A cross-sectional study was carried out of the results of cervical/vaginal cytopathology evaluations obtained from women seeking gynecological assistance in the 33 health clinics in the municipality of Santo André/SP, in the period of January 2009 to December 2011.

The pap smears were stained by the Papanicolaou staining procedure, classified by the Bethesda system 2001, and analyzed by a cytotechnologist and reviewed by a cytopathologist. 
All of the cytopathology tests of women screened in the municipality of Santo André were included in the study, but test results relating to the following were excluded: insuficient material for analysis, acellular or hypocellular material, and slide analysis impaired by the presence of blood, artifacts caused by drying and external contaminants.

Test results were grouped according to the age of the women examined; the study group consisted of women under 25 years of age, i.e. adolescents and young women (MJA group); and the comparison group consisted of women 25 years old or older, referred to as adult women (MA group).

All of the procedures described were approved by the Research Ethics Committee of the Health Secretary of Santo André (no. 008/2012).

Data were inserted into an electronic Microsoft ${ }^{\circledR}$ Excel ${ }^{\circledR} 2007$ spreadsheet (Microsof ${ }^{\circledR}$, USA), and are shown as absolute and percent frequencies per group and year. The total number of abnormal tests per year and group are shown, as well as the frequencies of each type of abnormality.

Comparisons were carried out between groups by means of the chi-square test. The statistical software WinSTAT ${ }^{\circledR}$ for Microsoft ${ }^{\circledR}$ Excel ${ }^{\circledR}$, version 2007.1 was used (Robert K. Fitch, Germany).

\section{Results}

During the period of January 2009 to December 2011, 92,118 cytopathology tests were carried out of women in the municipality of Santo André, where 76,752 were in the MA group and 15,366 were in the MJA group. Of all the cytology tests, 89,723 (97.4\%) were considered to be normal and 2,395 (2.6\%) showed abnormalities.

From Table 1 it can be seen that of the 2,395 tests showing abnormalities, 1,278 (53.4\%) were represented by atypical squamous cells of undetermined significance (ASCUS); 900 (37.6\%) by lowgrade squamous intraepithelial lesion (LSIL) and $217(9.1 \%)$ by high-grade squamous intraepithelial lesion (HSIL). A statistically significant difference can be seen with regard to the year, with a greater proportion of ASCUS occurring in 2011 in comparison to previous years.

There was a statistically significant difference among groups, with higher rates of abnormal re-

Table 1. Total number of cytopathology tests showing abnormalities in women in the municipality of Santo André, classified according to abnormality and year.

\begin{tabular}{|l|c|c|c|c|}
\hline & ASCUS & LSIL & HSIL & Total \\
\hline 2009 & $349(46.8 \%)$ & $328(44.0 \%)$ & $69(9.2 \%)$ & $746(100 \%)$ \\
\hline 2010 & $316(48.5 \%)$ & $271(41.6 \%)$ & $65(10.0 \%)$ & $652(100 \%)$ \\
\hline 2011 & $613(61.5 \%)$ & $301(30.2 \%)$ & $83(8.3 \%)$ & $997(100 \%)$ \\
\hline Total & $1,278(53.4 \%)$ & $900(37.6 \%)$ & $217(9.0 \%)$ & $2,395(100 \%)$ \\
\hline
\end{tabular}

For years: $\chi^{2}=47.866 ; p<0.001$

Table 2. Normal and abnormal cytopathology tests in MJA and MA in the municipality of Santo André during the period of 2009 to 2011.

\begin{tabular}{|l|c|c|c|c|c|c|} 
& \multicolumn{2}{c}{ MJA } & \multicolumn{2}{c}{ MA } & Total & P \\
\cline { 2 - 6 } & Normal & Abnormal & Normal & Abnormal & & MJA vs. MA \\
\hline 2009 & $5,288(96.8 \%)$ & $174(3.2 \%)$ & $23,817(97.7 \%)$ & $572(2.3 \%)$ & 29,851 & $<0.001$ \\
\hline 2010 & $4,590(96.5 \%)$ & $164(3.4 \%)$ & $25,389(98.1 \%)$ & $488(1.9 \%)$ & 30,631 & $<0.001$ \\
\hline 2011 & $4,978(96.7 \%)$ & $172(3.3 \%)$ & $25,661(96.9 \%)$ & $825(3.1 \%)$ & 31,636 & 0.398 \\
\hline Total & $14,856(96.7 \%)$ & $510(3.3 \%)$ & $74,867(97.5 \%)$ & $1,885(2.5 \%)$ & 92,118 & $<0.001$ \\
\hline
\end{tabular}


sults for the MJA group for the years 2009, 2010 and for the total for all three years (Table 2).

Table 3 shows the total number of cytopathology abnormalities for groups MJA and MA according to the type of abnormality observed. Among adolescents and young adults, the most frequent abnormal result was LSIL, corresponding to $280(54.9 \%)$ of the 510 abnormal results in this group, whilst in the group of adults, ASCUS was the most frequent corresponding to 1,061 (56.3\%) of the 1,885 abnormal results. Although HSIL was the least frequent abnormality seen in both groups, it was found in $2.5 \%$ of women in the MJA group and in $10.8 \%$ of women in the MA group. The differences in frequency of the types of abnormalities among the groups were statistically significant.

Table 3. Cytopathological abnormalities observed in the MJA and MA groups classified according to type during the period of 2009 to 2011.

\begin{tabular}{|l|c|c|c|}
\multirow{2}{*}{} & \multicolumn{2}{|c}{ Groups } & \multirow{2}{*}{ Total } \\
\cline { 2 - 4 } & MJA & MA & \\
\hline ASCUS & $217(42.5 \%)$ & $1.061(56.3 \%)$ & $1.278(53.4 \%)$ \\
\hline LSIL & $280(54.9 \%)$ & $620(32.9 \%)$ & $900(37.6 \%)$ \\
\hline HSIL & $13(2.5 \%)$ & $204(10.8 \%)$ & $217(9.1 \%)$ \\
\hline Total & $510(100 \%)$ & $1.885(100 \%)$ & $2.395(100 \%)$ \\
\hline
\end{tabular}

Comparison between MJA and MA: $\chi^{2}=96.269 ; \mathrm{p}<0.001$

\section{Discussion}

According to the Ministry of Health, the number o women between 25 and 64 years old that should have been screened in 2010 was 198,061. In said year, 25,877 cytopathology tests were carried out in women over 25 years old by the SUS, which corresponds to $11.4 \%$ of the women in this age group, if one considers that each test corresponds to one woman, which is not always the case [11].

The total number of cytopathology tests carried out by the Brazilian healthcare system SUS of the municipality of Santo André/SP in the period of 2009 to 2011 was approximately 30,000 tests per year, for a total of 676,407 inhabitants, wherein 351,949 are women. Young women and adolescents correspond to $11.3 \%$ and women between 25 and 64 years of age correspond to $29.3 \%$ of the population of Santo André. The absolute number is approximately 270,000 women in the municipality of Santo André [12].

It can therefore be seen that the total number of cytology tests carried out by the SUS during the period of 2009 to 2011 corresponds to a little over $10 \%$ of this population. Of all the tests carried out in this period, $97.4 \%$ showed normal results and $2.6 \%$ abnormal results.

Cervical cancer screening is recommended in Brazil by the Ministry of Health for women 25 years old or older, which is similar to European countries [13]. The reason for starting screening at this age is due to the fact that only $1 \%$ of the cases of cervical cancer occur in women under this age [14].

The Fundação Oncocentro de São Paulo (FOSP) registered that between 2000 and 2009 there were 11,729 cases of invasive cancer, of which 121 cases occured in women under 25 years of age, wherein six were found to have stage 1, i.e. good prognosis, but not sensitive to the detection of precursory lesions [11].

The 2011 Technical Committee of the Ministry of Health (Comitê Técnico do Ministério da Saúde) recommends not screening women under 25 years of age. The reason for this decision is initially due to the transitory nature of HPV infection in adolescents [3].

One should also consider the rarity of the occurrence of cervical carcinoma in this age group, approximately $1 \%$ of cases, and that health resources should be directed to those at an age of higher occurrence. Current studies have also suggested that even when these young women have invasive lesions, these are not identified by current screening methods [15]. 
Although screening for cervical cancer in adolescents is not numerically justified, one should keep in mind that the disease can have a huge impact on the health of young women and future reproduction. Studies are necessary to adapt screening to local realities in terms of age, method and interval, with an urgent need for system organization and active search for women.

In the USA, screening begins at the age of 21, but only in women who have started sexual activity. It is recommended that colpocytology is carried out every three years between 21 and 29 years of age, even in the case of two consecutive negative results [16].

According to estimations of the National Cancer Institute's Surveillance Epidemiology and Results (SEER), cervical cancer is rare in adolescents, but there has been an increase in incidence among young women. There have also been signs of an increase in the incidence of pre-neoplasic lesions in increasingly younger women in the United States [17].

In the present study, ASCUS was the abnormality most found in adult women. A possible explanation for this would be the inclusion of women in their menopause. The Bethesda system recommends that these women receive estrogen stimulation, since the benign alterations caused by atrophy can be resolved whilst the pre-cancerous lesions persist and can be detected more easily in mature cells [18].

Young and adolescent women had LSIL as the most prevalent lesion, which can be explained by the fact that there is a high incidence of HPV infection in this age group, still not covered by the HPV vaccination, introduced into the Brazilian public health system beginning 10 March 2014.

Nascimento et al. have demonstrated in their study that cancer in adolescents is rare, but observed that alterations associated with cancer were present in women when still very young [19].

The treatment for HSIL is preferably done by excision of the transformation zone, which until recently was considered harmless in terms of obstetric consequences. However, a metanalysis has found a correlation between excisional treatment and an increase in the incidence of premature labour and low birth weight, and consequently several authors have become more conservative in terms of the conduct for cervical intra-epithelial neoplasia grade II (CIN II) in young women, such that currently only medical monitoring is recommended due to the high rate of regression of such lesions [20]. Ortoft et al. in their study also show increases in extreme prematurity and perinatal death in women previously subjected to conization procedures [21].

Screening of adolescents that frequently have a high incidence of HPV, but who also have high "viral clearance", could lead one to overestimate the diagnosis of precursory lesions and consequently over treat them, potentially functionally damaging the cervix and causing prematurity in the future.

On the other hand, the non-diagnosis of cervical cancer, which is extremely worrying although rare during this phase, can have a huge impact on the lives of these young women. However, the literature helps the current conduct by demonstrating that genital cancer in this age group has a different evolution in comparison to women over 25 years and is not very sensitive to screening methods [22].

It should be highlighted that not screening for cancer in these young women does not mean that inadequate care has been taken. Considering the growing incidence of STDs and precursory lesions of cervical cancer, programs and services for attending adolescents for early detection, treatment and prevention of STDs associated with vaccinations in general, including vaccination against HPV, are imperative and necessary.

The present study has revealed that HSIL are more common in women over 25 years as opposed to under this age. This reinforces the current conduct for carrying out screening starting at 25 years of age, 
although the data observed in the present study also suggest that the minimum cut-off age should be periodically re-evaluated considering that there is a higher percentage of abnormal results, particularly of LSIL, in younger women.

In conclusion, has been shown higher rates of cytopathological abnormalities in the group of women under 25 years of age in comparison to women over 25 . The younger women also had a higher rate of cytology results compatible with LSIL; however, the group of women over 25 years of age had a prevalence of HSIL approximately four times higher than the younger group.

\section{Funding}

This study was carried out without any source of funding. The authors alone were responsible for the expenses.

\section{Declaration of conflict of interest}

The authors declare they have no conflict of interest concerning this study.

\section{References}

1. Centro Brasileiro de Análise e Planejamento. Pesquisa Nacional de Demografia e Saúde da Criança e da Mulher - PNDS 2006. Brasília: Ministério da Saúde, 2009; 298 pp.

2. Ministério da Saúde. Pesquisa Nacional de Saúde do Escolar. Brasília: Ministério da Saúde, 2012, 251pp.

3. Instituto Nacional de Câncer. HPV e Câncer. Disponível em: http://mortalidade.inca.gov.br. Acesso em: 27/10/2014.

4. Derchain SFM, Pinto Neto AM, Oliveira RLC, Santos CL, Pinto e Silva JLC. Infecção por papilomavírus humano e neoplasia intraepitelial cervical em adolescentes. J Bras Ginecol. 1991; 101: 499-503.

5. Morrison EA, Ho GY, Vermud ST et al. Human papillomavirus infection and other risk factors for cervical neoplasia: a case control study. Int J Cancer. 1991; 49: 6-13.

6. Kahn JA, Goodmann E, Huang B, Slap GB, Emano SJ. Predictors of Papanicolaou smear in a hospital-based adolescent and young adult clinic. Obstet. Gynecol. 2003; 101(2): 490-9.

7. Instituto Nacional de Câncer. Estimativa de 2014 de incidência de câncer no Brasil. Disponível em: http://www.inca.gov.br/ estimativa/2014/sintese-de-resultados-comentários.asp. Acesso em: 17/08/2014

8. Lüdicke F, Stalberg A, Vassilakos P, Major AL, Campana A. High- and intermediate-risk human papillomavirus infection in sexually active adolescent females. J Pediatric Adolesc Gynecol. 2001; 14(4): 171-4.

9. Monteiro DLM. A cérvice uterina na adolescência: estudo da prevalência e fatores associados ao câncer de colo uterino e suas lesões precursoras em população de adolescentes no Rio de Janeiro. Dissertação de Mestrado. Rio de Janeiro: FIOCRUZ, 2004

10. Instituto Nacional de Câncer. Diretrizes brasileiras para o rastreamento do câncer do colo do útero. Rio de Janeiro: Instituto Nacional de Câncer e Ministério da Saúde, 2011, 104 pp.

11. Instituto Brasileiro de Geografia e Estatística (IBGE). Disponível em: http://www.cidades.ibge.gov.br/xtras/home.php. Acesso em 28/10/2014.

12. Instituto Brasileiro de Geografia e Estatística (IBGE). Disponível em: http://cod.ibge.gov.br/232PM. Acesso em 28/07/2014.

13. International Agency of Research on Cancer - IARC. Working Group on Evaluation of Cervical Cancer Screening Programmes. Screening for squamous cervical cancer: duration of low risk after negative results of cervical cytology and its implication for screening policies. BMJ. 1986; 293: 659-64.

14. Vale DB, Westin MC, Zeferino LC. High-grade squamous intraepithelial lesion in women aged $<30$ years has a prevalence pattern resembling low-grade squamous intraepithelial lesion. Cancer Cytopathol. 2013; 121(10): 576-81. 
15. Nascimento MI, Pires ES, GIL DQ et al. Características de um grupo de adolescentes com suspeita de neoplasia intraepitelial cervical. Rev Bras Ginecol Obstet. 2005; 27(10): 619-26.

16. Mello ES. Rastreamento do câncer do colo uterino: desafios e recomendações. Onco\& 2012; novembro/dezembro: 3035. Disponível em: http://www.revistaonco.com.br. Acesso: 20/12/2014

17. Insinga RP, Glass AG, Rush BB. Diagnoses and outcomes in cervical cancer screening: a populationbased study. Am J Obstet Gynecol. 2004; 191(1): 105-13.

18. Solomon D, Nayar R. Sistema Bethesda para Citologia Cervicovaginal. Rio de Janeiro: Revinter, 2005, 192 pp.

19. Nascimento MI, Pires ES, Gil DQ et al. Características de um grupo de adolescentes com suspeita de neoplasia intra-epitelial cervical. Rev Bras Ginecol Obstet. 2005; 27(10): 619-626.

20. Kyrgiou M, Koliopoulos G, Martin-Hirsch P et al. Obstetric outcomes after conservative treatment for intraepithelial or early invasive cervical lesions: systematic review and metaanalysis. Lancet 2006; 367(9509): 489-98.

21. Ortoft $G$, Henriksen $T$, Hansen $E$, Petersen L. After conisation of the cervix, the perinatal mortality as a result of preterm delivery increases in subsequent pregnancy. BJOG 2010; 117(3): 258-67.

22. Cirino FMSB, Nichiata LYI, Borges ALV. Conhecimento, atitude e práticas na prevenção do câncer de colo uterino e HPV em adolescentes. Esc Anna Nery Rev Enferm. 2010; 14(1): 126-34. Disponível em: http://www.revistaenfermagem.eean.edu.br. Acesso em: 20/12/2014.
Comment on this article:

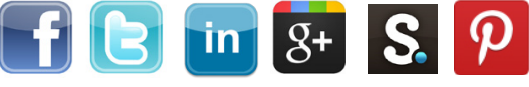

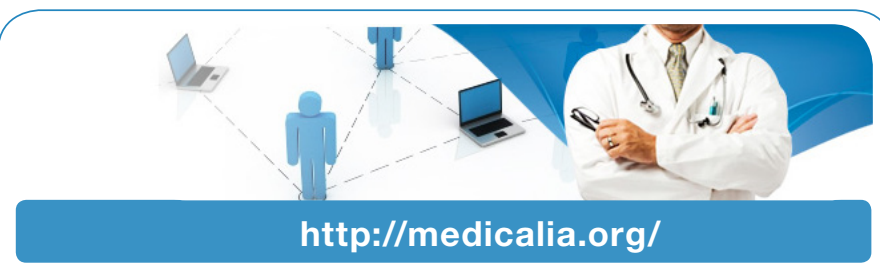

Where Doctors exchange clinical experiences, review their cases and share clinical knowledge. You can also access lots of medical publications for free. Join Now!

\section{Publish with iMedPub}

http://www.imed.pub

International Archives of Medicine is an open access journal publishing articles encompassing all aspects of medical science and clinical practice. IAM is considered a megajournal with independent sections on all areas of medicine. IAM is a really international journal with authors and board members from all around the world. The journal is widely indexed and classified Q1 in category Medicine. 